\title{
Novel Anti-Streptococcal Peptide Produced by Mangrove Bacteria Bacillus subtilis
}

\author{
Joseph Sahayarayan Jesudass ${ }^{1 *}$, Karthikeyan Kandasamy ${ }^{3}$, \\ Sathyamoorthi Thangavelu ${ }^{2}$ and Arivoli Appavu ${ }^{4}$
}

\author{
${ }^{1}$ Department of Bioinformatics, ${ }^{2}$ Department of Microbiology, Alagappa University, \\ Karaikudi 630003, India \\ ${ }^{3}$ Department of Food Science and Nutrition, Periyar University, Salem 636011, India \\ ${ }^{4}$ Department of Environmental Sciences, Government Arts College, Ariyalur 621713, India \\ *Corresponding author
}

\section{A B S T R A C T}

\begin{tabular}{|l|}
\hline Ke y w o r d s \\
Bacillus subtilis, \\
Streptococcus mutans, \\
Antimicrobial, \\
Muthupet mangrove, \\
Anti-streptococcal \\
peptide
\end{tabular}

\section{Introduction}

Coastal ecosystem is a dynamic ecosystem, links terrestrial and marine ecosystems. Mangrove is a unique coastal ecosystem covered by many unique plant populations. Mangrove plants provide shelter for many living things (Ganesh Kumar et al., 2010; Vasanthi et al., 2014; Jha et al., 2013; Balakrishnan et al., 2014, 2017a; Chai et al., 2017; Baskar and PrabaKaran, 2015, 2011a,b). Mangrove-associated bacteria tend to produce an enormous variety of antibacterial
Streptococcus mutans is a primary dental pathogen causes dental caries, its multidrug resistance increases the complications in treating the diseases. Many bacteria in a microbially rich environment like mangrove ecosystem tend to produce a variety of antimicrobial compounds. In the present study, a bacterium was isolated which showed excellent anti-streptococcal activity against human oral pathogen Streptococcus mutans. Antibacterial activity not recorded for any other pathogens used. The active bacterium identified as Bacillus subtilis using phenotypic characterization. Further, the active compound from the culture supernatant of B. subtilis was partially purified by precipitation and solvent extraction. The active compound proved to be a peptide in nature. The minimal inhibitory concentration (MIC) of the partially purified anti-streptococcal peptide was $123 \pm 10 \mu \mathrm{g} \mathrm{ml}^{-1}$, which is comparable to commercial antibiotics. The antistreptococcal peptide found in the study can be evaluated for its use in treating dental diseases. compounds for their survival in the highly competing niche (Balakrishnan et al., 2014; Prakash et al., 2015).

Bacteria can act as consortia to perform interactive and defensive mechanisms in a presenting environment or host and can operate as a sole living entity. This consortium called the microbiome; recently microbiological research focused on microbiome analysis to find the role of each bacteria to act as consortia (Balakrishnan et al., 2017b; Balakrishnan and Mobley, 2017). 
Among oral pathogens, Streptococcus mutans is an important pathogen causes dental caries (Ahrari et al., 2015). Increasing multidrug resistance of $S$. mutans leads the way to search new antimicrobial compounds from the natural environment. Apart from multidrug resistance pathogenic bacteria like E. coli, Streptococcus, Salmonella, and Shigella tend to change their antigenic properties; this leads troubles in the strain level detection process (Barizuddin et al., 2015; Balakrishnan et al., 2016). In the present study, tried to isolate a potential bacterium with excellent antibacterial properties against the dental pathogen $S$. mutans. The isolated bacteria characterized up to species level using phenotypic characterization. Also, partially purified the active compound using precipitation and extraction techniques.

Mangrove soil samples collected from Mangrove ecosystem of Muthupet, Tamil Nadu, India (Lat: 10²0'20.5"N Lan: $79^{\circ} 32^{\prime} 36.8^{\prime \prime E}$ ). Isolation was performed using marine agar plates. From the isolation procedure isolated 60 different bacteria and screened for antibacterial activity against $S$. mutans. Antimicrobial activity performed using disc diffusion assay using supernatant of the marine broth cultures of purified isolates.
Among the isolates, one of them showed excellent anti-streptococcal activity. Phenotypic characterization of the active strain performed as per Bergey's Manual of Systematic Bacteriology (Logan and Vos, 2015). Based on the results the isolate identified as Bacillus subtilis (Table 1). There are several reports proved to isolate antibioticproducing bacterial species from mangrove environment. Recently in our previous research project, we identified a $B$. cereus which showed a wide range of antimicrobial activity against many human pathogenic bacteria (Karthikeyan and Sahayarayan, 2017).

The present study also tested antibacterial activity of $B$. subtilis against other common bacteria such as Bacillus subtilis, Enterococcus faecalis, Escherichia coli, Klebsiella pneumonia, Micrococcus luteus, Proteous mirabilis, Pseudomonas aeruginosa, Salmonella enterica, Shigella flexineri and Staphylococcus aureus. However, the active bacteria did not show any antibacterial activity against the above-listed bacteria. The results confirm that the antibiotic produced by $B$. subtilis specific to $S$. mutans among the tested bacteria (Fig. 1).

Table.1 Phenotypic characters of $B$. subtilis

\begin{tabular}{|l|c|l|c|l|c|}
\hline Test & Result & Test & Result & Test & Result \\
\hline Colony colour & White & $\mathrm{H}_{2}$ S Production & - & Glucose & + \\
\hline Grams staining & + & Catalase & + & Glycerol & + \\
\hline Motility & + & Oxidase & + & Inositol & + \\
\hline Spore production & + & Urease & - & Lactose & - \\
\hline pH range & $4-10$ & Gelatinase & + & Maltose & + \\
\hline Optimum pH & $7 \pm 0.2$ & Nitrate Reductase & + & Mannitol & + \\
\hline Temperature ${ }^{\circ} \mathrm{C}$ & $10-45$ & Arginine decarboxylase & + & Mannose & + \\
\hline Optimum ${ }^{\circ} \mathrm{C}$ & $37 \pm 0.2$ & Lysine decarboxylase & - & Raffinose & + \\
\hline Range of $\mathrm{NaCl}(\%)$ & $0.5-10$ & Ornithin decarboxylase & - & Rhamnose & - \\
\hline Optimum $\mathrm{NaCl}(\%)$ & 0.5 & Arabinose & + & Sorbitol & + \\
\hline Indole & - & Cellobiose & + & Sucrose & + \\
\hline Methyl Red & + & Dextrose & + & Starch & + \\
\hline Voges Proskauer & + & Fructose & + & Trehalose & + \\
\hline Citrate & + & Galactose & + & Xylose & + \\
\hline
\end{tabular}


Fig.1 Antimicrobial activity of $B$. subtilis against $S$. mutans. A; Initial antibacterial screening using culture supernatant, showing a zone of inhibition. B; Partially purified anti-streptococcal peptide showed higher antibacterial activity than supernatant

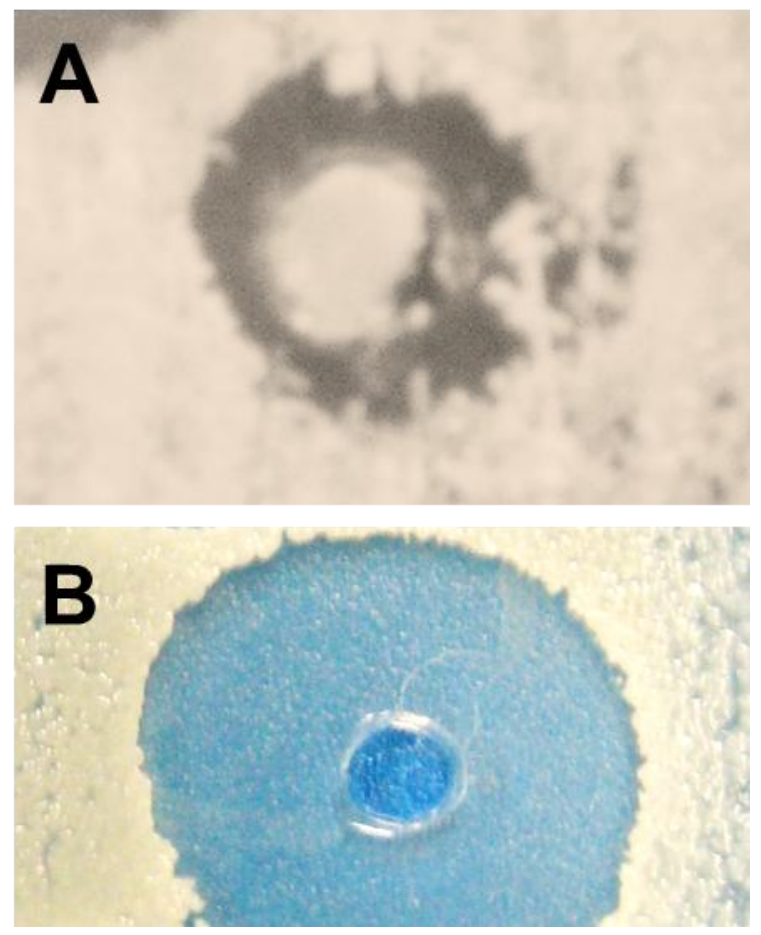

We suspected the antimicrobial compound is a proteinaceous substance (antimicrobial peptide). Partial purification of the antimicrobial compound carried out using culture supernatant of the bacterium in marine broth. The supernatant was precipitated using $60 \%$ ammonium sulphate saturation, followed by butanol extraction as described by Balakrishnan et al., (2014). To prove proteinaceous nature; enzymatic treatments carried using lipase, pepsin, catalase, trypsin, lysozyme, and proteinase $\mathrm{K}$. where the compound inactivated by proteolytic enzymes thus the active compound proved to be a protein-based compound.

MIC of the partially purified compound was tested using serial dilution method. The active compound showed MIC of $123 \pm 10 \mu \mathrm{g} \mathrm{ml}{ }^{-1}$ against $S$. mutans. This level is nearly comparable to commercial antibiotics like penicillin $\left(108 \pm 02 \mathrm{\mu g} \mathrm{ml}^{-1}\right)$ and erythromycin $\left(98 \pm 01 \mu \mathrm{g} \mathrm{ml}^{-1}\right)$. If the compound is purified, it will show much lower MIC value, and that will make this compound more active than any other antibiotic used in treating dental caries. Balakrishna et al., (2014) demonstrated the same thing for vibriocin, where the antibacterial efficiency of the active compound logarithmically increased after each step of purification. Many research studies proved on identify antimicrobial compounds from mangrove sediments. Only a few studies demonstrated the nature of the antimicrobial compound produced by associated mangrove bacteria (Hwanhlem et al., 2014; Balakrishnan et al., 2014). In the present study, the compound showed to be a protein in nature. Possibly the compound is an antimicrobial peptide. Similar kind of antimicrobial peptide reported from Vibrio parahaemolyticus and the peptide active against only pathogenic Vibrios (Balakrishnan et al., 2014). Based on the present study the 
anti-streptococcal peptide identified can be used in treating dental caries by controlling the growth of $S$. mutans in parts of the oral cavity.

\section{Acknowledgement}

Author thankful to Dr. J. Jeyakanthan (Professor and Head, Department of Bioinformatics, Alagappa University, India) for his continuous support and encouragement in doing research.

\section{References}

Ahrari, F., Eslami, N., Rajabi, O., Ghazvini, $\mathrm{K}$ and Barati, S. 2015. The antimicrobial sensitivity of Streptococcus mutans and Streptococcus sangius to colloidal solutions of different nanoparticles applied as mouthwashes. Dental Research Journal, 12(1): 44-49.

Balakrishnan, B. and Mobley, G. 2017. Next in Human Microbiome Research. EC Microbiol. 6: 91-92

Balakrishnan, B., Barizuddin, S., Wuliji, T. and El-Dweik, M. 2016. A rapid and highly specific immunofluorescence method to detect Escherichia coli O157:H7 in infected meat samples. Int. J. Food Microbiol. 231: 54-62. doi.org/10.1016/j.ijfoodmicro.2016.05.0 17

Balakrishnan, B., Ranishree, J.K., Thadikamala, S. and Panchatcharam, P. 2014. Purification, characterization and production optimization of a vibriocin produced by mangrove associated Vibrio parahaemolyticus. Asian Pac. J. Trop. Biomed. 4: 253-261. doi.org/10.12980/APJTB.4.2014C947.

Balakrishnan, B., Sahu, B.K., Ranishree, J.K., Lourduraj, A.V., Nithyanandam, M., Packiriswamy, N. and Panchatcharam, P. 2017a. Assessment of heavy metal concentrations and associated resistant bacterial communities in bulk and rhizosphere soil of Avicennia marina of Pichavaram mangrove, India. Environ. Earth Sci. 76: 58 doi.org/10.1007/s12665-016- 6378-7.

Balakrishnan, B., Luckey, D., Marietta, E., Karau, M., Patel, R., Murray, J and Taneja V. 2017b. Development of a real-time PCR method for quantification of Prevotella histicola from the gut. Anaerobe. 3(48): 37-41. doi: 10.1016/j.anaerobe.2017.06.019.

Barizuddin, S., Balakrishnan, B., Stringer, R.C. and Dweik, M. 2015. Highly specific and rapid immuno-fluorescent visualization and detection of $E$. coli O104:H4 with protein-A coated magnetic beads based LST-MUG assay. J. Microbiol. Methods. 115: 27-33. doi.org/10.1016/j.mimet.2015.05.017.

Baskar and PrabaKaran 2011a. characterization of Mangrove Associated Nitrogen Fixing Halophilic Bacterium Paenibacillus sp. International Journal of Current Research. 3(9): 065-067.

Baskar, B. and PrabaKaran, B. 2011b. Isolation and characterization of copper resistant Exiguobacterium strains isolated from rhizosphere soil of Avicennia marina. Res. J. Pharm. Biol. Chem. Sci. 2(4): 640-646.

Baskar, B. and PrabaKaran, B. 2015. Assesment of nitrogen fixing bacterial community present in the rhizosphere of Avicennia marina. Indian J. Geomar. Sci. 44(3): 318-322.

Chai, M., Li, R. and Zan, Q. 2017. Effects of Mangrove plants on heavy metal risk in sediment based on SEM-AVS analysis. Reg. Stud. Mar. Sci. 13: 12-18.

Ganesh Kumar, A., Baskar, B., Santhanakumar, J., Vinithkumar, N.V., Vijayakumaran, M. and Kirubagaran, R. 2010. Diversity and functional 
properties of intestinal microbial flora of the spiny lobster Panulirus versicolor (Latreille, 1804). J. Mar. Biol. Ass. India. 52(2): 282-285.

Hwanhlem, N., Chobert, J.M. and H-Kittikun, A. 2014. Bacteriocin-producing lactic acid bacteria isolated from mangrove forests in southern Thailand as potential bio-control agents in food: Isolation, screening and optimization. Food Contr. 41: 202-11.

Jha, D.K., Vinithkumar, N.V., Marimuthu, N., Baskar, B., Da,s A.K., Sahu, B.K. and Kirubagaran, R. 2013. Field and GIS based assessment of scleractinian coral cover in the Aerial Bay group of islands, north Andaman, India. J Coast Conserv. 17: 671-677. doi:10.1007/s11852-013-0266-z.

Karthikeyan, K. and Sahayarayan J. 2017. Antibacterial Activity of a Novel Bacillus cereus isolated from Mangrove Ecosystem. Int. J. Curr. Microbiol. App. Sci. 6(8): 3302-3306.
Logan, N A. and Vos, P.D. 2015. Bacillus. Bergey's Manual of Systematics of Archaea and Bacteria. 1-163. doi: 10.1002/9781118960608.gbm0053 0 .

Prakash, S., Ramasubburayan, R., Iyapparaj, P., Ahila, N.K., Ramkumar, V.S., Palavesam, A., Immanuel, G. and Kannapiran, E. 2015. Influence of physicochemical and nutritional factors on bacterial diversity in mangrove sediments along the southwest coast of Tamilnadu, India. Environ. Monit. Assess. 187: 562.

Vasanthi, L.A., Muruganandam, A., Revathi, P., Baskar, B., Jayapriyan, K., Baburajendran, R and Munuswamy, N. 2014. The application of histocytopathological biomarkers in the mud crab Scylla serrata (Forskal) to assess heavy metal toxicity in Pulicat Lake, Chennai. Mar. Pollut. Bull. 81: 85-93. doi.org/10.1016/j.marpolbul.2014.02.01 6.

\section{How to cite this article:}

Joseph Sahayarayan Jesudass, Karthikeyan Kandasamy, Sathyamoorthi Thangavelu and Arivoli Appavu. 2018. Novel Anti-Streptococcal Peptide Produced by Mangrove Bacteria Bacillus subtilis. Int.J.Curr.Microbiol.App.Sci. 7(01): 1374-1378.

doi: https://doi.org/10.20546/ijcmas.2018.701.167 